\title{
Physical properties of constitutive size classes of spray-dried skim milk powder and their mixtures
}

\author{
Jean-Luc ILARI*, Laila MEKKAOUI \\ Dpt. Génie des Procédés Alimentaires, GEPEA, Enitiaa, BP 82225, 44322 Nantes cedex, France
}

Published online 12 July 2005

\begin{abstract}
Skim milk powder is a very valuable industrial ingredient, the properties of which are dependent on process and running conditions. We studied a powder obtained from a third generation dryer, its size fractions, and two experimental binary mixes of fractions for physical properties and use, including flowability. The results indicate special properties for one class, i.e. the [100-112 $\mu \mathrm{m}]$ fraction. The correlation of characteristics is reported, and practical consequences concerning the process and the quality are discussed.
\end{abstract}

skim milk powder / size fraction / powder physical property / flowability

Résumé - Propriétés physiques des différentes classes constitutives d'une poudre de lait écrémé obtenue par atomisation et de leurs mélanges. Une poudre de lait écrémé, traitée sur un séchoir de $3^{\mathrm{e}}$ génération précédant les installations MSD (Multi Stage Dryer), a été tamisée et étudiée avec ses fractions sur une panoplie de grandeurs physiques et comportementales, dont celles d'écoulement. Deux mélanges binaires de fractions, incluant la classe particulière [100-112 $\mu \mathrm{m}]$ ont été aussi analysés. Les résultats obtenus et l'étude des corrélations entre grandeurs mesurées conduisent à des réflexions concrètes pour la mesure de la qualité des poudres et le choix réfléchi des installations industrielles.

propriété physique / poudre de lait écrémé / granulométrie / écoulement

\section{INTRODUCTION}

Powdered foods are having greater and greater significance in the food industry. They can be readily stored and play critical economical and technical roles in food formulation. Their behaviour is very versatile, and depends on a great number of factors, often difficult to control and predict.

Those interested in the theoretical basis of powder behaviour study very simplified powder models, which are far from reality as they are "monodispersed". The main difficulty is that natural powders are very often "polydispersed" for many characteristics including, of course, size. Moreover, all the chemical engineering theories are only applicable to monodispersed particles, as, for example, they use only the value of one diameter to introduce the particle size within calculations. There is therefore a need for a practical and experimental approach.

\footnotetext{
* Corresponding author: ilari@enitiaa-nantes.fr
} 
The first aim of this study was to establish an overview of the properties of size classes for skim milk powder. The initial approach was to characterise the different classes for better end-use properties. The second was to separate classes in order to obtain a wider scale of properties and the technological use of the whole fractions, thus building a sort of discrimination rule. Food powders are generally a wide mix of dry particles, with a size dispersion depending on technological factors characterised by an average diameter $\left(\mathrm{D}_{\text {aver }}\right)$ different from $\sum_{i=1}^{n} \frac{D_{\text {aver }_{i}}}{n}$ and with intrinsic properties, which are always different from simple addition of initial particle properties.

Another aim was to compare the properties of the initial size classes and the properties of some binary mixes of these classes, with the general purpose of better industrial management of powder size classes to extend their use and the market.

Skim milk powder is a special product as it contains high levels of proteins and lactose. The crystallisation equilibrium and behaviour of lactose (amorphous, or crystallised with one water molecule) is a major factor in the evolution of the powder. When applying our analytical tools to this kind of product, it was necessary to be very sensitive to the neighbouring hygrometric conditions. Caking and surface crystallisation of lactose are the well-known possibilities of evolution that must be avoided by good control of the physical parameters in neighbouring or storage conditions.

\section{MATERIALS AND METHODS}

\subsection{Products and technological parameters}

Skim milk powder for human consumption was provided by Epi Ingredients (run of 15/10/01), a large industrial provider in our region (Ancenis, France). Milk was pasteurised at $90^{\circ} \mathrm{C}$ for $30 \mathrm{~s}$, steam concentrated under vacuum to $45 \%$ dry matter, and dried in a spray dryer with incoming air at $204^{\circ} \mathrm{C}$ and an outside temperature of $88^{\circ} \mathrm{C}$.
The pulverisation pressure was 180 bar. The dryer comprised a cylindro-conical chamber where the concentrate was dispersed, followed by two fluidised beds. The beds were shaken to obtain more homogeneous treatment for each particle through the shearing effects. Storage of samples, class size sampling and mixing were performed in closed containers and hermetic glassware in a temperature-controlled room $\left(20^{\circ} \mathrm{C}\right)$.

\subsection{Moisture content of powders and water activity}

Moisture content (4\%) was measured according to the official IDF method [13] applied to a 5-g sample in a ventilated oven at $103 \pm 2{ }^{\circ} \mathrm{C}$.

Water activity (0.17) was measured at $20{ }^{\circ} \mathrm{C}$ with an electrical hygrometer (Humidat RC from Novasina, Pfäffikon, Switzerland).

\subsection{Sieving of fractions}

Sieving of fractions was performed on a laboratory sieve machine ("Rotachoc" from Tripette and Renaud, Villeneuve la Garenne, France), following the French norm AFNOR [1], $50 \mathrm{~g}$ of sample being sieved for 6 min at 120 revolutions $\cdot \mathrm{min}^{-1}$, and with $71,80,90,100,112,125,140,160$ and $180 \mu \mathrm{m}$ sieves.

\subsection{Mixing of fractions}

Two binary mixes were prepared inside a three-dimensional manual mixer (Bioblock, Illkirch, France) and 1.7-litre glassware. Two binary mixes $\left(\mathrm{M}_{1}\right.$ and $\left.\mathrm{M}_{2}\right)$ were prepared with $41 \%$ of the $[100-112 \mu \mathrm{m}]$ fraction and $59 \%$ of the $[140-160 \mu \mathrm{m}]$ for $\mathrm{M}_{1}$. and $38 \%$ of the $[100-112 \mu \mathrm{m}]$ and $62 \%$ of the [71-80 $\mu \mathrm{m}$ ] for $\mathrm{M}_{2}$. We first checked with the standard deviation value, that the mix was ready in 3 min. rotation time.

\subsection{Size measurements}

The average sizes and size distributions of the different samples were checked with a laser diffraction Malvern Mastersizer (Malvern Instruments SA, Orsay, France). 
Size distribution was evaluated directly by the integrated software with the classical dispersion index span $\left(\frac{D_{90}-D_{10}}{D_{50}}\right)$.

\subsection{Image analysis}

Pictures of dry particles on a glass plate were obtained with a polarised microscope and a Charge Couple Device camera.

Pictures were digitised with an electronic card Matrox MVP, and then analysed with Visilog 5.4 software (Noesis, Courtabeuf, France). Shape factor was defined as: $\mathrm{F}=4 \pi \mathrm{A} / \mathrm{P}^{2}$, with $\mathrm{A}$ the projected area of the particle and $\mathrm{P}$ the perimeter. The $\mathrm{F}$ value was 1 for a pure sphere and between 0 and 1 for all other shapes.

\subsection{Particle density}

Particle density, $\rho_{p}$ (also known as $\rho_{\text {true }}$ ), was measured with an Accupyc 1330 pycnometer (Micrometrics, Creil, France) using pure helium, and porosity was calculated as $\varepsilon=1-\frac{\rho_{\mathrm{Ant}}}{\rho_{\mathrm{P}}}$, with an apparent density of $\rho_{\text {Ant }}\left(\rho_{\text {A }}\right.$ not tapped $)$ according to the Hosokawa powder flow analyser.

\subsection{Physical properties}

Physical properties were obtained using a methodology derived from the behaviour testing procedures of Carr [3-5] with a powder flow analyser (Micrometrics Laboratory, Hosokawa, Japan) recommended by other authors $[7,15]$ as an analyser with good reproducibility. The parameters measured included calculated Hausner ratio, calculated compressibility, angles of fall, repose and difference, angle of spatula, and flowability and floodability indices (the last two included in the scale [0-100]).

\subsection{Inclined plane}

According to Devise et al. [6] and Graindorge [9], the horizontal plane turns to vertical at $1.75 \times 10^{-3} \mathrm{rad} \cdot \mathrm{s}^{-1}$. The initial conical powder pile was built on the horizontal plane with the Hosokawa tester device. We then observed the time of "first particle slipping" and then the whole pile slipping (the angles measured were slip angle $\alpha_{\text {slide }}$, and flow angle $\alpha_{\text {flow }}$, together with their difference $D_{\text {flow }}=\alpha_{\text {flow }}-\alpha_{\text {slide }}$.

The inclined plane and Carr's methodologies both provided angle values which were interesting to compare.

\subsection{Statistical methods}

Pearson's correlation measures the closeness of a linear relationship between two variables. If one variable can be expressed exactly as a linear function of another variable, then the correlation is 1 or -1 , depending on whether the two variables are directly or inversely related. A correlation of zero means that each variable has no linear ability predictive of the other.

The "Statgraphics Plus" software, version 5.0, from Manugistics Inc., Rockville, USA, was used to carry out statistical tests, and $P<0.05$ was considered to be statistically significant for all statistical tests. This software makes it possible to compute ANOVA. Least significant difference (LSD), which compares average values and aggregates some results in homogeneous groups, was used to compare results.

\section{RESULTS AND DISCUSSION}

\subsection{Properties of initial skim milk powder and its sieve fractions}

The initial skim milk powder (ISMP) sample provided the size distribution histogram and cumulated histogram shown in Figures 1 and 2. Table I gives the size distribution classes in weight, D50 and the span values. The powder comprised a multimodal population, with a very high percentage of fine particles and particles under $71 \mu \mathrm{m}$. The fine class contained the highest number of particles. Many particles are linked together. Laser size measurement does not give the structure of these powders. We do not know whether the constitutive particles were isolated or presented a co-operative and/or developing structure. It is very 
Table I. Main size and shape characteristics of the powder and its constitutive classes.

\begin{tabular}{cccccc}
\hline Original sample and & & \multicolumn{2}{c}{ Particle size } & Porosity & Shape factor \\
\cline { 3 - 6 } size classes $(\mu \mathrm{m})$ & \% in weight & D50 $(\mu \mathrm{m})$ & Span & $(\%)$ & $0<\mathrm{F}<1$ \\
\hline ISMP & & 66.34 & 1.93 & 58.6 & 0.7827 \\
$>180$ & 4.73 & 218.38 & 1.43 & 63.0 & 0.6425 \\
$160-180$ & 2.62 & - & - & - & - \\
$140-160$ & 7.33 & 137.64 & 1.23 & 60.1 & 0.6075 \\
$125-140$ & 7.9 & 116.63 & 1.26 & 59.0 & 0.6075 \\
$112-125$ & 8.9 & 102.76 & 1.3 & 58.6 & 0.5521 \\
$100-112$ & 5.11 & 98 & 1.12 & 56.6 & 0.5853 \\
$90-100$ & 12.7 & 75.56 & 1.42 & 58.7 & 0.6286 \\
$80-90$ & 8.32 & 78.77 & 1.18 & 59.5 & 0.6283 \\
$71-80$ & 8.39 & 73.69 & 1.14 & 57.5 & 0.5996 \\
$<71$ & 33.73 & 44.73 & 1.35 & 60.2 & 0.6082 \\
Total & 99.32 & & & & \\
\hline
\end{tabular}

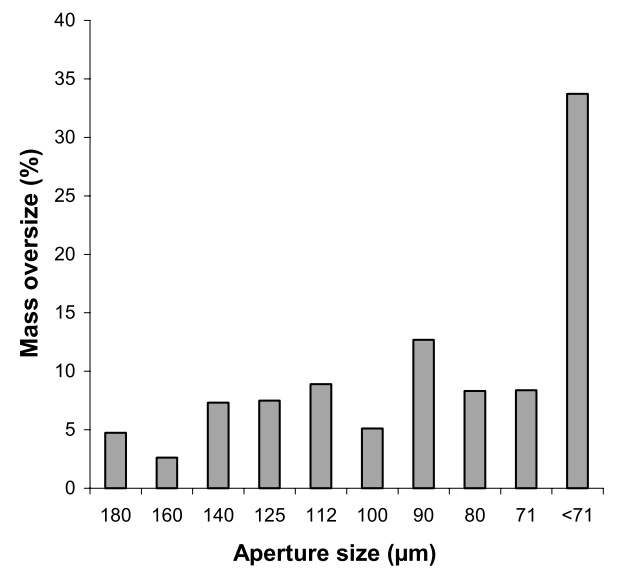

Figure 1. Mass histogram of skim milk powder.

difficult to hypothesise and understand the connection between the first pulverised liquid droplets of a concentrate and the final dry powder particle properties, as many unit operations and some parameter values are involved.

The quantity of the [160-180 $\mu \mathrm{m}]$ class was not sufficient to be studied through the analysis. The D50 value of $66 \mu \mathrm{m}$ for ISMP was low, corresponding to a high number of fine particles, and 1.93 for span indicated a very wide size distribution. It is normal for each D50 to be close to the size limits of each sieve class, and it is curious that the largest fraction [90-100 $\mu \mathrm{m}], 12.5 \%$ in weight, obtained a low D50 value $(75 \mu \mathrm{m})$. All these results are a consequence of previous sieving which separated the classes, and show the limitations of size measurements by using two methods, i.e. sieving and laser diffraction.

The shape factor did not present significant differences for the populations studied. It can be seen in Figure 2 that the majority of particles of the size fractions were agglomerated, and we obtained a kind of homogeneity for this shape factor. For ISMP, the shape factor $(0.78)$ was closer to 1 than that of each constitutive fraction. This result was a consequence of the influence of adsorbed fine particles which, in the case of fractions, could separate during the sieving of size classes. Fine particles are known to have a negative effect on the practical end-use properties of a given powder. They also have a delicate influence on the perception of shape of agglomerates, as they can fill holes. 


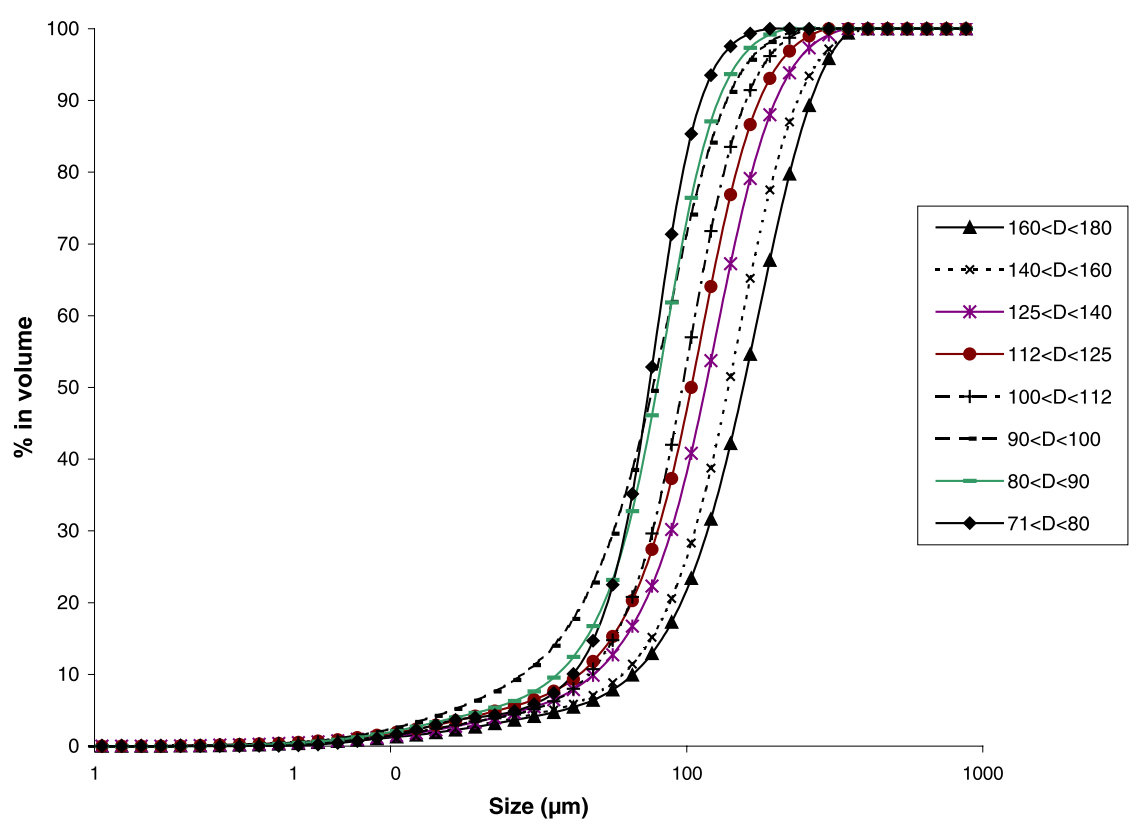

Figure 2. Cumulative particle size distribution of classes.

It could be thought initially that the largest particles would present the highest porosity, in view of the geometrical model of spherical particles. This is true only for fractions over $180 \mu \mathrm{m}$. However, segregation can impose some disturbance inside the system, and thus explains this kind of result. The low value of porosity seems discriminant for the [100-112 $\mu \mathrm{m}]$ class. It could be explained by a better ordering of constitutive particles during drying and better surface regularity or structure.

Fine particles themselves show a good sphericity as the small droplets of concentrate are rapidly dried and "spheronised" by surface-active forces. But they also agglomerate.

For the binary mixes $\mathrm{M} 1$ and $\mathrm{M} 2$ results are given in Table II and Figure 3. The shapes of the histograms differ for M1 and M2. The D50 was just below the constitutive percentage, and the span was very low. It would appear that some powder structures change during the mixing of binary populations. However, the porosity seemed to be stable. When we observed these particles, it became evident that they were part of a structured organisation, depending on their random meeting. Plasticity of materials does exist throughout the first drying period, allowing deformation and stabilised contacts. Particle associations (agglomerates and aggregates) present multi-orientation because of many possible factors (e.g. probabilities, trajectories, number of contacts, and plastic interactions linked to the real size of each initial droplet). At this point, a microscopic study of ISMP, fractions and mixes was performed. A selection is presented in Figure 4. These electronic pictures indicated that we could perform complementary image analysis. However, the microscopic views of each fraction could not be considered as a real measurement of the size and shape of the particles, but as a qualitative evaluation (although they originated from the quantitative software results). 


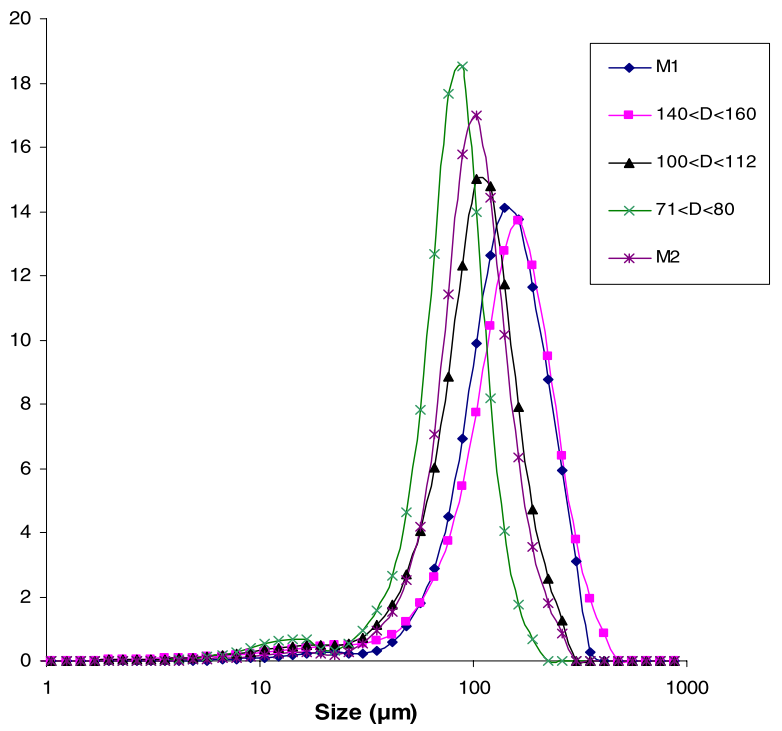

Figure 3. Size classes of mixes, M1 and M2, with their three constitutive classes.

Table II. Characteristics of the powder and of the two selected mixes, constructed from two particle size classes including the [100-112 $\mu \mathrm{m}]$ fraction.

\begin{tabular}{lcccc}
\hline Sample & $\begin{array}{c}\text { D50 } \\
(\mu \mathrm{m})\end{array}$ & Span & $\begin{array}{c}\text { Porosity } \\
(\%)\end{array}$ & $\begin{array}{c}\text { Shape factor } \\
0<\mathrm{F}<1\end{array}$ \\
\hline ISMP & 66.34 & 1.93 & 58.6 & 0.7827 \\
Mix M $_{1}$ & 132.28 & 1.16 & 58.0 & - \\
$41 \%[100-112]$ & & & & - \\
$59 \%[140-160]$ & & & 58.0 & \\
Mix M & & & & \\
$38 \%[100-112]$ & & & & \\
$62 \%[71-80]$ & & & & \\
\hline
\end{tabular}

There is a degree of chance in the choice of the particles, and it is too time-consuming to achieve a valid number of particles in each sample (theoretically close to 300 ).

Our long experience of this kind of study indicates that these results provide very good and complementary information on sieve and laser size measurements. Some particle size measurement companies now recommend these techniques themselves, and have developed special equipment for the pharmaceutical industry.
The study of a milk powder under a microscope (or a binocular magnifier) is a multidimensional measurement method, as many magnifications and changes in the number of objects studied, light, etc. can be used. To check homogeneity or identify a powder, you need low magnification and a representative high number of particles in the field. For example, a photograph of the ISMP can be considered as an identity card of the particle population, and a valuable characterization. 

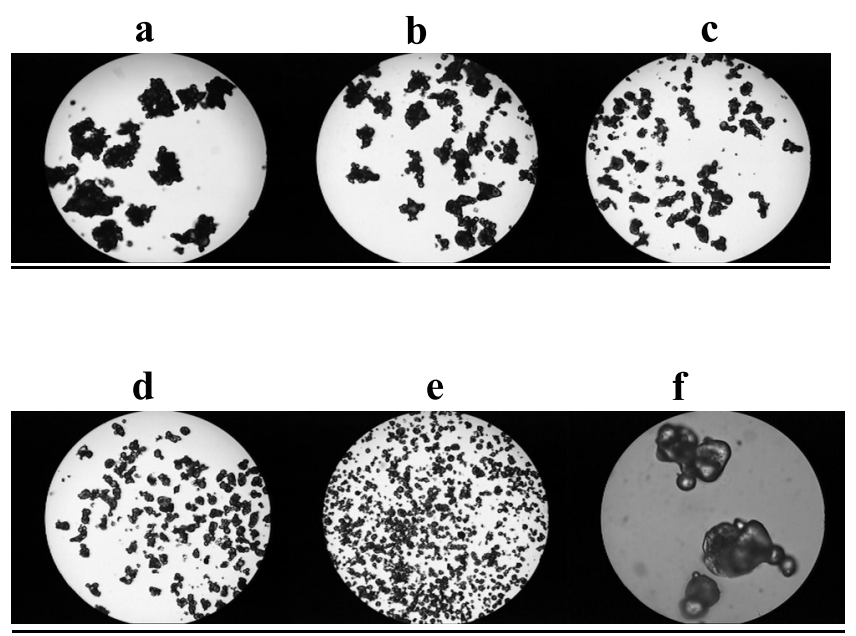

Figure 4. Optical images of the powder and its constitutive size classes. (a) class $>180 \mu \mathrm{m}$;

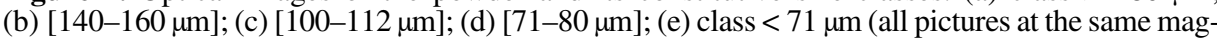
nification); (f) class [100-112 $\mu \mathrm{m}]$ at a larger magnification: the number of particles included in the aggregate remains under 10 .

\subsection{Hausner ratio (behaviour of powder)}

Hausner's reference study [12] shows the value of the ratio between the tapped $\rho_{\text {At }}$ and not tapped $\rho_{\text {Ant }}$ apparent densities of the powder. $\rho_{\text {At }}$ and $\rho_{\text {Ant }}$ are easily measured using the Hosokawa tester, following Carr's procedures [4]. Tapping was applied 180 times in 6 min.

Many studies in the pharmaceutical industry $[6,18]$ have used the Hausner ratio as an indicator for the cohesion of a powder. This index is very dependent on the changes in structure inside the powder bed, as a consequence of the size, shape and association of constitutive solid particles. For each product these changes can be an indicator of both the differences in processing and in operational management and machinery adaptation. This index should therefore be very valuable in many other industries to characterise both the powder and the influence of the dryer, or even just one of these if the other is constant.

Figure 5 shows that the Hausner ratio goes down when the average particle size of a size class goes up, as a function of $1 / D_{\text {aver }}^{0.2}$.

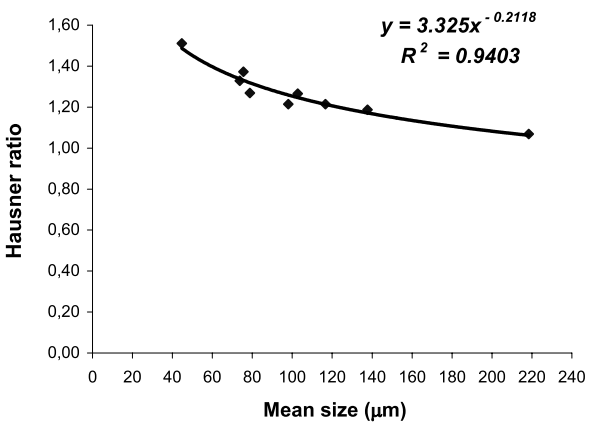

Figure 5. Variations in Hausner ratio according to size classes of skim milk powder.

This confirms our previous results [16] with other powders. Using this size scale for food powders, larger size is correlated with lower cohesion, and as a consequence of less friction and poor Van der Walls forces, the flow behaviour becomes better and more homogeneous with more regular shape. These three factors are of considerable industrial importance. The Hausner ratio has also been developed by Geldart et al. [8] for classification of powders. Each size 
Table III. Properties and characteristics of the two prepared mix powders including the [100-112 $\mu \mathrm{m}]$ fraction.

\begin{tabular}{|c|c|c|c|c|c|c|c|c|c|c|c|c|}
\hline $\begin{array}{c}\% \text { of } \\
\text { classes } \\
\text { in the mix }\end{array}$ & $\begin{array}{c}\text { Average } \\
\text { size } \\
\text { D50 } \\
(\mu \mathrm{m})\end{array}$ & $\begin{array}{l}\text { Angle } \\
\text { of } \\
\text { repose } \\
\left({ }^{\circ}\right)\end{array}$ & $\begin{array}{c}\text { Angle } \\
\text { of } \\
\text { fall } \\
\left(^{\circ}\right)\end{array}$ & $\begin{array}{c}\text { Angle } \\
\text { of } \\
\text { difference } \\
\left(^{\circ}\right)\end{array}$ & $\begin{array}{c}\text { Angle } \\
\text { of } \\
\text { spatula } \\
\left(^{\circ}\right)\end{array}$ & $\begin{array}{c}\text { Compres- } \\
\text { sibility } \\
(\%)\end{array}$ & $\begin{array}{c}\text { Hausner } \\
\text { ratio }\end{array}$ & $\begin{array}{c}\text { Density } \\
\text { increase by } \\
\text { tapping } \\
\left(\mathrm{kg} \cdot \mathrm{m}^{-3}\right)\end{array}$ & $\begin{array}{c}\text { Porosity } \\
\text { (\%) }\end{array}$ & $\begin{array}{c}\text { Particle } \\
\text { density } \\
\text { pycno } \\
\left(\mathrm{kg} \cdot \mathrm{m}^{-3}\right)\end{array}$ & $\begin{array}{c}\text { Loose } \\
\text { density } \\
\left(\mathrm{kg} \cdot \mathrm{m}^{-3}\right)\end{array}$ & $\begin{array}{l}\text { Tapped } \\
\text { density } \\
\left(\mathrm{kg} \cdot \mathrm{m}^{-3}\right)\end{array}$ \\
\hline $\begin{array}{c}\text { M1: 41\% } \\
{[100-112] ;} \\
59 \% \\
{[140-160]}\end{array}$ & 132.3 & 40.8 & 28.2 & 12.7 & 65.2 & 14.9 & 1.18 & 96 & 58 & 1280 & 543 & 638 \\
\hline $\begin{array}{c}\text { M2: } 38 \% \\
{[100-112] ;} \\
62 \% \\
{[71-80]}\end{array}$ & 92.9 & 43.2 & 26.7 & 16.5 & 62.8 & 23.9 & 1.31 & 171 & 58 & 1293 & 544 & 715 \\
\hline
\end{tabular}

Table IV. Main properties and flowability and floodability values.

\begin{tabular}{ccccccccccc}
\hline $\begin{array}{c}\text { Original sample } \\
\text { and size classes } \\
(\mu \mathrm{m})\end{array}$ & $\begin{array}{c}\text { Compressi- } \\
\text { bility } \\
(\%)\end{array}$ & $\begin{array}{c}\text { Hausner } \\
\text { ratio }\end{array}$ & & $\begin{array}{c}\text { Geldart } \\
\text { class }\end{array}$ & $\begin{array}{c}\text { Density } \\
\text { increase by } \\
\text { tapping } \\
\left(\mathrm{kg} \cdot \mathrm{m}^{-3}\right)\end{array}$ & $\begin{array}{c}\text { Poro- } \\
\text { sity } \\
(\%)\end{array}$ & $\begin{array}{c}\text { Particle } \\
\text { density } \\
\text { pycno } \\
\left(\mathrm{kg} \cdot \mathrm{m}^{-3}\right)\end{array}$ & $\begin{array}{c}\text { Floodabi- } \\
\text { lity }\end{array}$ & $\begin{array}{c}\text { Flowabi- } \\
\text { lity }\end{array}$ & $\begin{array}{c}\text { Span } \\
\text { Cohesive- } \\
\text { ness }\end{array}$ \\
\hline ISMP & 31.3 & 1.46 & $\mathrm{C}$ & 250 & 58.6 & 1300 & 75.83 & 43.0 & 1.93 & 48.6 \\
$>180$ & $6.5 \mathrm{a}$ & $1.07 \mathrm{a}$ & $\mathrm{D}$ & $30 \mathrm{a}$ & $63.0 \mathrm{f}$ & $1290 \mathrm{f}$ & $72.41 \mathrm{a}$ & $61.75 \mathrm{e}$ & $1.43 \mathrm{f}$ & $37.4 \mathrm{~cd}$ \\
$140-160$ & $15.7 \mathrm{~b}$ & $1.19 \mathrm{~b}$ & $\mathrm{~A}$ & $103 \mathrm{~b}$ & $60.1 \mathrm{e}$ & $1280 \mathrm{c}$ & $83.66 \mathrm{~d}$ & $59.58 \mathrm{~d}$ & $1.23 \mathrm{c}$ & $39.5 \mathrm{~d}$ \\
$125-140$ & $17.6 \mathrm{~b}, \mathrm{c}$ & $1.21 \mathrm{~b}$ & $\mathrm{~A}$ & $107 \mathrm{~b}$ & $59.0 \mathrm{~d}$ & $1272 \mathrm{a}$ & $81.41 \mathrm{c}, \mathrm{d}$ & $59.25 \mathrm{~d}$ & $1.26 \mathrm{c}, \mathrm{d}$ & $29.6 \mathrm{~b}$ \\
$112-125$ & $21.0 \mathrm{~d}$ & $1.27 \mathrm{c}$ & AC & $148 \mathrm{~d}$ & $58.6 \mathrm{c}$ & $1280 \mathrm{~b}$ & $80.41 \mathrm{c}$ & $55.5 \mathrm{c}$ & $1.3 \mathrm{~d}$ & $35.2 \mathrm{c}$ \\
$100-112$ & $17.6 \mathrm{c}$ & $1.21 \mathrm{~b}$ & A & $135 \mathrm{c}$ & $56.6 \mathrm{a}$ & $1273 \mathrm{~b}$ & $81.00 \mathrm{c}, \mathrm{d}$ & $65.66 \mathrm{f}$ & $1.12 \mathrm{~b}$ & $25.5 \mathrm{a}$ \\
$90-100$ & $27.1 \mathrm{e}$ & $1.37 \mathrm{~d}$ & AC & $206 \mathrm{f}$ & $58.7 \mathrm{~b}, \mathrm{c}$ & $1282 \mathrm{~d}$ & $77.33 \mathrm{~b}$ & $48.25 \mathrm{~b}$ & $1.42 \mathrm{f}$ & $63.6 \mathrm{e}$ \\
$80-90$ & $21.2 \mathrm{~d}$ & $1.27 \mathrm{c}$ & AC & $149 \mathrm{e}$ & $59.5 \mathrm{~d}$ & $1390 \mathrm{~h}$ & $78.58 \mathrm{~b}, \mathrm{c}$ & $49.41 \mathrm{~b}$ & $1.18 \mathrm{~b}$ & $65.8 \mathrm{e}$ \\
$71-80$ & $24.7 \mathrm{e}$ & $1.33 \mathrm{~d}$ & AC & $190 \mathrm{f}$ & $57.5 \mathrm{~b}$ & $1292 \mathrm{e}$ & $78.91 \mathrm{~b}, \mathrm{c}$ & $48.58 \mathrm{~b}$ & $1.14 \mathrm{a}$ & $62.6 \mathrm{e}$ \\
$<71$ & $33.8 \mathrm{f}$ & $1.51 \mathrm{e}$ & $\mathrm{C}$ & $275 \mathrm{~g}$ & $60.2 \mathrm{e}$ & $1321 \mathrm{~g}$ & $72.75 \mathrm{a}$ & $34.67 \mathrm{a}$ & $1.35 \mathrm{e}$ & $73.6 \mathrm{f}$ \\
\hline
\end{tabular}

The same letter following two results (e.g. 3rd column $1.19 \mathrm{~b}$ and $1.21 \mathrm{~b}$ ) means that through LDS testing these results are not statistically different $(P<0.05)$.

class therefore has specific and different properties. For ISMP powder and size classes, we can apply Geldart's classification, related to behaviour in fluidisation. According to Geldart, for the same product, the decrease in particle size leads to classes $\mathrm{D}, \mathrm{A}, \mathrm{AC}$ and $\mathrm{C}$, the lowest size corresponding to the most cohesive powder. The values that we obtained for the Hausner ratio (Fig. 5, Tabs. III and IV) strongly indicate that factors other than size influence this index. For mixes $\mathbf{M}_{1}$ and $\mathrm{M}_{2}$, the Hausner ratio presented the same tendency, decreasing with increasing particle size. Variation in this parameter is sensitive to size variations and also to other factors. Parameter $\rho_{\text {Ant }}$ for mix $M_{1}$ was lower than that for mix $\mathrm{M}_{2}$, because there were not enough fine particles to fill the holes between other particles.

Finally, the behaviour of the mix could be predicted with the Hausner ratio, as the Hausner ratio correlated with cohesiveness, Geldart's classification [8] for fluidised bed, compressibility and roughly with flowability. The cohesiveness of a given powder therefore cannot only be explained by particle size. In this case, lactose, fatty acids, moisture and other chemical components also contribute to the inter-particle relationships, and molecule behaviour is also dependent on the drying parameters that can induce changes in the physical state. 


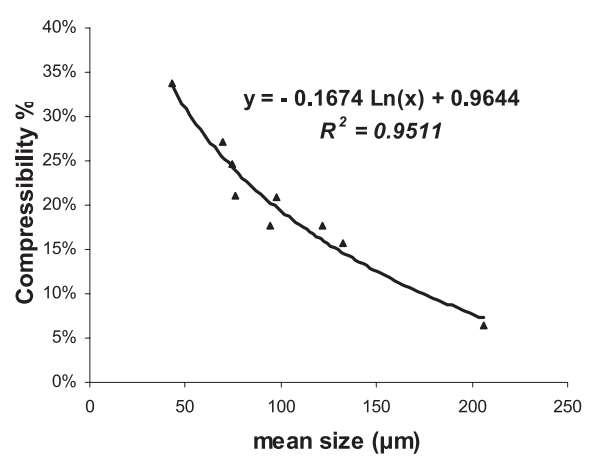

Figure 6. Compressibility according to size for fractions of skim milk powder.

\subsection{Compressibility}

Compressibility is the ability to reduce volume by tapping, developed by Carr [4] as an average and indirect measure of cohesion forces $\left[\left(1-\rho_{\text {Ant }} / \rho_{\text {At }}\right) \times 100\right]$. Generally speaking, a powder with a compressibility $>28 \%$ presents poor flowability and is classified as cohesive [12]. The results are presented in Figure 6 and showed nearly the same tendency as for the Hausner ratio. Compressibility is normally dependent on size distribution of constitutive particles. It can easily be linked to different unit operations used in powder industries, such as preparation, compaction, measuring out and packaging. It also helps to understand "arching" during storage in bins and silos.

Compressibility for the two binary mixes $\left(\mathbf{M}_{1}\right.$ and $\left.\mathbf{M}_{2}\right)$ followed the same tendency as the Hausner ratio, declining when average size increased.

\subsection{Study of the different angles}

Although the angle of repose is the best known, further information can be obtained from the measurements of other angles. All the results for angles are given in Table V and their variation in Figure 7.

\subsubsection{Angle of repose (Ar)}

The angle of repose is the more classical measurement under gravity proposed by Carr [4] and has been used for the last fifty years. It is obtained by control of distribution through a vibrating sieve, whereby the powder falls before being stopped by the horizontal surface, and the falling speed is regulated by a controlled vibrating sieve.

It is known that this angle is dependent on size, shape, size distribution, surface roughness of particles, porosity of the bed, and on moisture within and in the neighbouring environment [19]. For a value of angle of repose over $40^{\circ}$ the powder is

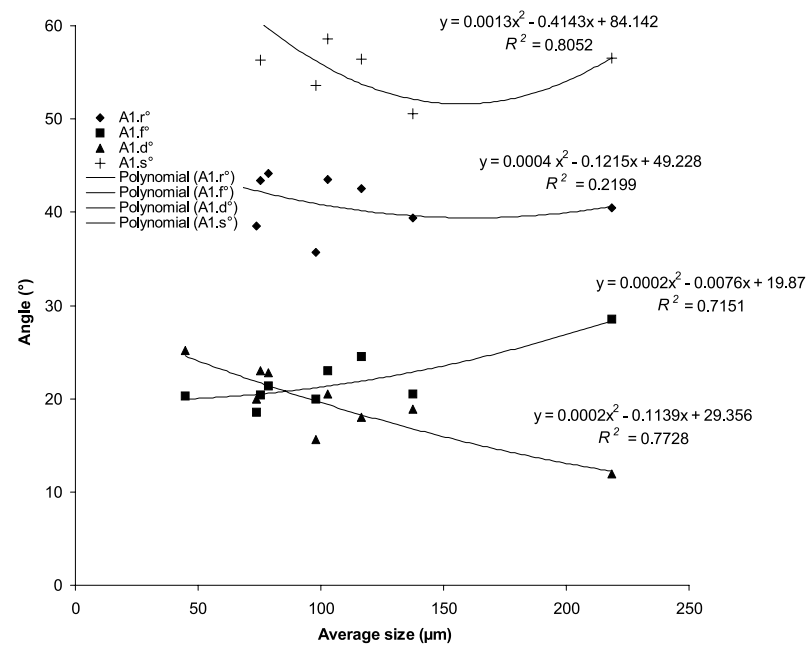

Figure 7. Angles according to size classes of skim milk powder. 
Table V. Values of the angles for the different size classes.

\begin{tabular}{ccccccccc}
\hline $\begin{array}{c}\text { Original sample } \\
\text { and size classes } \\
(\mu \mathrm{m})\end{array}$ & $\begin{array}{c}\text { D50 } \\
(\mu \mathrm{m})\end{array}$ & $\begin{array}{c}\text { Angle of } \\
\text { repose } \\
\left({ }^{\circ}\right)\end{array}$ & $\begin{array}{c}\text { Angle of } \\
\text { fall } \\
\left({ }^{\circ}\right)\end{array}$ & $\begin{array}{c}\text { Angle of } \\
\text { difference } \\
\left({ }^{\circ}\right)\end{array}$ & $\begin{array}{c}\text { Angle of } \\
\text { spatula } \\
\left({ }^{\circ}\right)\end{array}$ & $\begin{array}{c}\text { Angle of } \\
\text { slide } \\
\alpha_{\text {slide }} \\
\left({ }^{\circ}\right)\end{array}$ & $\begin{array}{c}\text { Angle } \\
\text { of flow } \\
\alpha_{\text {flow }}\end{array}$ & $\begin{array}{c}\text { Difference } \\
\left(^{\circ}\right)\end{array}$ \\
\hline ISMP & 66.3 & 41.8 & 20.5 & 21.3 & 74.5 & 13.1 & 46.1 & 33 \\
$>180$ & $218.4 \mathrm{a}$ & $40.4 \mathrm{c}$ & $28.6 \mathrm{e}$ & $11.9 \mathrm{a}$ & $56.5 \mathrm{c}$ & $24.0 \mathrm{~g}$ & $33.1 \mathrm{a}$ & $9.1 \mathrm{a}$ \\
$140-160$ & $137.6 \mathrm{~b}$ & $39.3 \mathrm{~b}$ & $20.5 \mathrm{~b}$ & $18.8 \mathrm{~d}$ & $50.6 \mathrm{a}$ & $19.0 \mathrm{~d}, \mathrm{e}$ & $40.2 \mathrm{~d}$ & $21.1 \mathrm{c}$ \\
$125-140$ & $116.6 \mathrm{c}$ & $42.6 \mathrm{~d}$ & $24.5 \mathrm{~d}$ & $18.1 \mathrm{c}$ & $56.5 \mathrm{c}$ & $17.5 \mathrm{c}, \mathrm{d}$ & $39.1 \mathrm{c}, \mathrm{d}$ & $21.6 \mathrm{c}$ \\
$112-125$ & $102.8 \mathrm{~d}$ & $43.5 \mathrm{~d}$ & $23.0 \mathrm{c}$ & $20.5 \mathrm{e}$ & $58.5 \mathrm{c}$ & $20.4 \mathrm{e}, \mathrm{f}$ & $35.8 \mathrm{a}, \mathrm{b}, \mathrm{c}$ & $15.4 \mathrm{~b}$ \\
$100-112$ & $98.0 \mathrm{e}$ & $35.7 \mathrm{a}$ & $20.0 \mathrm{~b}$ & $15.7 \mathrm{~b}$ & $53.6 \mathrm{~b}$ & $20.8 \mathrm{e}, \mathrm{f}$ & $35.3 \mathrm{a}, \mathrm{b}$ & $14.5 \mathrm{~b}$ \\
$90-100$ & $75.6 \mathrm{~g}$ & $43.4 \mathrm{~d}$ & $20.4 \mathrm{~b}$ & $23.0 \mathrm{f}$ & $56.3 \mathrm{~b}$ & $22.7 \mathrm{f}, \mathrm{g}$ & $35.0 \mathrm{a}, \mathrm{b}$ & $12.3 \mathrm{a}, \mathrm{b}$ \\
$80-90$ & $78.7 \mathrm{f}$ & $44.1 \mathrm{~d}$ & $21.3 \mathrm{~b}$ & $22.8 \mathrm{f}$ & $60.3 \mathrm{c}$ & $15.5 \mathrm{~b}, \mathrm{c}$ & $38.0 \mathrm{~b}, \mathrm{c}, \mathrm{d}$ & $22.6 \mathrm{c}$ \\
$71-80$ & $73.7 \mathrm{~h}$ & $38.5 \mathrm{~b}$ & $18.5 \mathrm{a}$ & $20.0 \mathrm{~d}$ & $61.5 \mathrm{~d}$ & $14.3 \mathrm{~b}$ & $37.5 \mathrm{~b}, \mathrm{c}, \mathrm{d}$ & $23.2 \mathrm{c}$ \\
$<71$ & $44.7 \mathrm{i}$ & $45.5 \mathrm{e}$ & $20.3 \mathrm{~b}$ & $25.2 \mathrm{~g}$ & $69.4 \mathrm{e}$ & $12.8 \mathrm{a}$ & $53.0 \mathrm{e}$ & $40.2 \mathrm{~d}$ \\
\hline
\end{tabular}

The same letter following two results (e.g. 3rd column $42.6 \mathrm{~d}$ and $43.5 \mathrm{~d}$ ) mean that through LDS testing these results are not statistically different $(P<0.05)$.

considered cohesive and with poor flowability [22]. There can be difficulties with the determination of angles with this ISMP: fine particles which are very sensitive to friction can produce a new cone on the top of the normal cone, due to an electrostatic effect, giving real difficulties in reading. Moreover, the angles of repose of ISMP size classes present a particular behaviour. They should increase with the decrease in size, as proposed by Wouters and Geldart [22]. However, classes [100-112 $\mu \mathrm{m}]$ and [71-80 $\mu \mathrm{m}]$ did not display this tendency. Other properties of powder could probably explain this.

The size class [100-112 $\mu \mathrm{m}]$ was really different from all the other classes as it presented the lowest value for the angle of repose. It should therefore have had the best flowability.

Table III gives the results obtained by the analysis of the two prepared mixes (M1 and M2) to be compared with both the ISMP and its constitutive size classes. It is easy to verify for these two mixes that particle size (D50) plays a role in other properties. The angle of repose was thus lower for larger and higher for smaller sizes.

Working with pharmaceuticals, Pilpel [19] found $\mathrm{Ar}=\mathrm{AD}_{\text {aver }^{-1}+\mathrm{B} \text { usable for any }}$ diameter, where $\mathrm{A}$ and $\mathrm{B}$ are constants.
Another model $\left(\mathrm{Ar}=\mathrm{a}+\mathrm{b} \log \mathrm{D}_{\text {Sauter }}\right)$ was also proposed by Wouters and Geldart [22].

Neither of these two possible equations applied to our product. However, the angle of repose was sensitive, depending on many parameters, such as fine particle content, density homogeneity, shape irregularities, and the shape of particles themselves. The great number of parameters influencing the angle of repose for a food powder makes modelling very difficult. Normally, the angle of repose is linked to flowability, but as an integrating measurement, it should be correlated with other parameters linked to flowability, such as the Hausner ratio [22]. It will be seen below that they are not correlated. Powder evolution may be the main factor in the difference (minimisation of particle interactions and evolution of empty volume of the powder).

Variations in size of the different angles are given in Figure 7, together with models.

\subsubsection{Angle of fall (Af) and angle of difference $(A d)$}

The angle of fall is measured after a change in angle of repose following a precise vibration. When the built powder cone falls, it is normal to interpret that some gas (generally air) trapped in the structural 
holes inside the powder bed which has initially been "expanded", becomes free.

Falls of particles very often become an avalanche (or successive partial avalanches) giving a new angle to the slope. A high value angle of difference (Ar-Af) indicates that the powder is easily moved at the beginning of a fall.

\subsubsection{Angle of spatula (AS)}

The angle of spatula is an average value between two measurements performed on a powder after bulk deposition on a horizontal spatula, which is then lifted by a normalised method to minimise bias. A high AS value indicates very poor flow properties, as static particles consolidate over time under gravity and other neighbouring factors. An AS over $90^{\circ}$ often corresponds to very cohesive powders.

\subsection{Flowability and floodability}

These indices are behaviour properties, obtained by simple addition of transformed values of previous items, following the Hosokawa methodology according to Carr [3]. These indices are the weighted addition of four other previous behaviour measurements [15]. The flowability scale is "universal", as it has been constructed on previous measurements of 300 different powders, from [0-19] very poor, [20-39] poor, [40-59] not good, [60-69] normal, [70-79] good, [80-89] fairly good and [90-100] very good. All the dairy powders that we have studied since 1977 have been under the value of 60, corresponding to "normal flowability" [15].

\subsection{Comparison between ISMP and its constitutive size classes}

Table IV compares properties of the ISMP and of its constitutive size classes. Note that a powder presents a normal flow, without special problems with a flowability index value of 60 . Only the class with smaller size particles $(\mathrm{D}<71 \mu \mathrm{m})$ presented worse flowability (34) than ISMP (43); ISMP cannot present good flowability because of its wide range of particle size and a high number of small particles.
The size class [100-112 $\mu \mathrm{m}]$ presented extreme values for each characteristic evaluated, such as a low compressibility (17.6\%), the lowest span (1.12), the lowest cohesiveness (25.5), and even the lowest specific weight using the pycnometer, and also a low Hausner ratio (1.21), together with the best flowability index with an incredible value of 65.7. This class should therefore present high internal homogeneity of particles and quite "exceptional properties" within the series studied. This flowability index value is quite unusual for dairy powders [15].

Classes over $125 \mu \mathrm{m}$ presented flowability close to 60 or above $(59.3 ; 59.6 ; 61.8)$, meaning that these powder fractions would not present technical difficulties for their processing. They belong to Geldart's class $\mathrm{A}$ and should behave well during fluidisation, the main structural operation in the drying process as it includes agglomeration.

Apart from class sizes under $73 \mu \mathrm{m}$, each size class also presented better flowability than the whole powder itself. This result is important in itself. Only the fine fraction $(\mathrm{D}<71 \mu \mathrm{m})$ presented another behaviour, which was easily understandable because of the cohesiveness of particle systems obtained with only fine particles [2]. It can be seen that for this powder homogenising size of particles through sieving led to new size classes, each theoretically an identical product (chemically speaking) but with specific physical properties. Greater control of the end use of each fraction can therefore be expected from analysis.

\subsection{Statistical study and matrix information}

With the ISMP, its different size fractions and the two binary mixes, we obtained a series of powders of the same composition, but with different average particle sizes.

Statistical study was applied to evaluate the effects of dispersion of size classes on powder properties, using the methodology that we have already used for milk and egg powders [9-11, 14] and providing a correlation matrix. Pearson's matrix correlation is presented in Table VI.

Carr [3] constructed the concept of flowability on a linear combination from values 


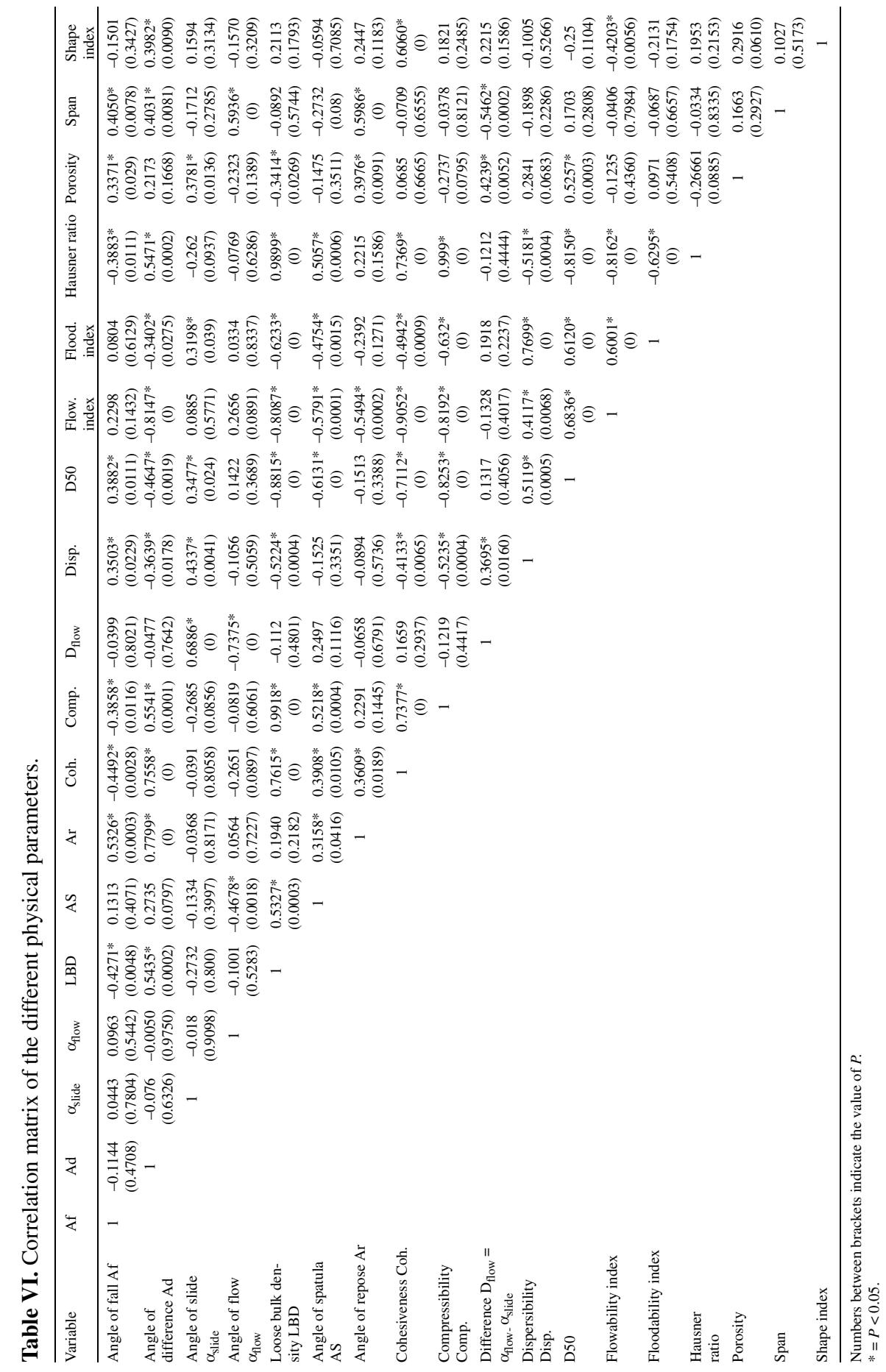


of angle of repose, angle of spatula, cohesiveness and compressibility, and thus a normal correlation does exist. Floodability is another linear combination of flowability, angle of fall, angle of difference and dispersibility. This also provides a normal correlation. However, we were above all interested in other possible correlations which might appear in the matrix and their significance in the specific case of ISMP and its size fractions.

The average size (or D50) was mainly correlated with flowability $(0.6836, P=0)$, floodability $(0.6120, P=0)$, Hausner ratio $(-0.8150, P=0)$, porosity $(0.5257$, $P=0.0003)$, density increase by tapping, $(-0.8815, P=0)$, angle of spatula $(-0.6131$, $P=0)$, cohesiveness $(-0.7112, P=0)$, compressibility $(-0.8253, P=0)$, dispersibility (0.5119, $P=0.0005)$, angle of difference ( $-0.4647, P=0.0019)$, angle of fall $(0.3882$, $P=0.0111)$ and angle of flow (0.3477, $P=0.024$ ), but not at all with angle of repose.

Angle of repose itself was almost correlated with span $(0.5986, P=0)$, cohesiveness $(0.3609, P=0.0189)$, porosity $(0.3976$, $P=0.0091)$ and angle of spatula $(0.3158$, $P=0.0416)$. The first correlation confirmed that heterogeneous particle populations (or dispersed populations) present a high value for angle of repose. Because of size and shape dispersions, the internal links inside the particle bed are more numerous with a polydispersed population which presents more contact points inside the powder bed.

Angle of fall was highly correlated with density increase by tapping $(-0.4271$, $P=0.0048)$, angle of repose $(0.5326$, $P=0.0003)$ it was derived from, cohesiveness $(-0.4492, P=0.0028)$, compressibility $(-0.3858, P=0.0028)$, span $(0.405$, $P=0.0078)$, dispersibility $(0.3503$, $P=0.0229)$, D50 (0.3882, $P=0.0111)$, Hausner ratio $(-0.3883, P=0.0111)$ and porosity $(0.3371, P=0.029)$. Angle of fall was really an integrated evaluation of the powder bed behaviour, including many properties of the constitutive particles.

Angle of difference was normally correlated with the same parameters as the angle of repose and angle of fall it derived from, and also with the shape factor $(0.3982$,
$P=0.009)$, confirming that for these kinds of dairy powder the shape influences the particle bed behaviour.

Angle of spatula was correlated with D50 $(-0.6131, P=0)$, Hausner ratio $(0.5057$, $P=0.0006)$, compressibility $(0.5218, P=$ $0.0004)$, angle of slide $(-0.4678, P=0.0018)$, cohesiveness $(0.3908, P=0.0105)$ and angle of repose $(0.3158, P=0.0416)$. This concept evaluates internal cohesion of a particle bed when a powder is under the influence of universal gravity.

The angle of slide was correlated with dispersibility $(0.4337, P=0.0041)$, D50 $(0.3477, P=0.024)$ and porosity $(0.3781$, $P=0.0136)$. These factors indicate that the way we prepare the particle bed before this measurement (powder pile) must be controlled and constant. The angle of slide was correlated with the angle of spatula $(-0.4678$, $P=0.0018)$, and highly correlated with span $(0.5936, P=0)$. This could be explained by the fact that the friction of particles on the slide are dependent on the cohesiveness of the bed and its roughness. Cohesiveness and roughness are a consequence of particle bed structure, which is itself dependent on size, shape and dispersion. For this particular skim milk powder, angle of slide was obtained by the flow of a cohesive mass, and not by successive avalanches as for glass ball powders. This indicates a certain degree of powder cohesiveness and internal cohesion.

Density increase by tapping was correlated with angle of spatula $(0.5327, P=0.0003)$, angle of difference $(0.5435, P=0.0002)$, cohesiveness $(0.7615, P=0)$, dispersibility $(-0.5224, P=0.0004)$ and D50 $(-0.8815$, $P=0)$. This last correlation shows that finer particles more easily become denser, as their bed is initially more expanded. Such density increase ability leads to much greater cohesiveness of the bed.

Cohesiveness was highly correlated with compressibility $(0.7377, P=0)$, dispersibility $(-0.4133, P=0.0065)$, D50 $(-0.7112$, $P=0)$, Hausner ratio $(0.7369, P=0)$, density increase by tapping $(0.7615, P=0)$, shape factor $(0.6060, P=0)$, angle of repose $(0.3609, P=0.0189)$, angle of fall $(-0.4492, P=0.0028)$ and angle of spatula $(0.3908, P=0.0105)$. This could be explained 
by the fact that the shape of particles for these products influences the contacts and their number, with a "puzzle effect" explaining cohesiveness. When we studied the relationships between compressibility and other factors, then between dispersibility and other factors, we could understand the opposition between compression, which induces cohesiveness, and dispersibility which requires no cohesiveness. The main factor which influences cohesiveness and dispersibility is the D50, as the bed geometry of model spherical particles suggests.

The Hausner ratio was first correlated with the D50 $(-0.8150, P=0)$ but also with angle of fall $(-0.3883, P=0.0111)$, angle of spatula $(0.50057, P=0.0006)$, cohesiveness $(0.7369, P=0)$ and dispersibility $(-0.5181$, $P=0.0004)$. All this confirms the high value of the Hausner ratio for an integrated characterisation of properties of this kind of powder.

Other integrated concepts developed by Carr, such as flowability, were correlated with the shape factor $(-0.4203, P=0.0056)$ and dispersibility $(0.4117, P=0.0068)$, factors linked to the behaviour of a powder in gas/solid suspension. The factors with the greatest influence on flowability are compressibility and angle of difference, which reduce the value of this index, and particle size (D50) only increases this index.

Floodability also normally followed the flowability it depended on, and was correlated with D50 $(0.6836, P=0)$. Fine particles present a special behaviour, usually called "dusty". Dustiness of milk powders, evaluated by floodability, presents some difficult problems for transfer, measuring out of bins, and manufacturing within the food industry, giving a white coating to all machinery, and presenting risks of contamination and difficulties in ensuring traceability. This can also affect certain human allergies, cleaning methodology and processing, and biological and/or cross-pollution problems for the process machinery.

\section{CONCLUSION}

This ISMP, spray-dried and partially agglomerated during drying, was studied on the size scale 0-200 $\mu \mathrm{m}$ (particularly $70-140 \mu \mathrm{m}$ after sieving).

The properties of this powder are a consequence of the thermodynamic conditions of drying, together with the structure of the constitutive particles induced, whether simple or complex. The structure and properties of both particles and powder are partially connected to the final size of the particles [21]. The population fractions therefore present different behaviours. Some of the measurements we performed concern primary, genuine or generic characteristics, such as D50, span or shape factor. Other characteristics, the behaviour ones, depend on the previous ones and on the geometrical or the neighbouring situation [16]. Behaviour factors integrate other ones, and should be explained by the primary factors.

Our results therefore lead to the following conclusions: although its definition is critical when applied to a population of different particle structures such as those of skim milk powder, D50 influences the compressibility and cohesiveness of the powder. The "dispersion index span" influences angle of repose and $\mathrm{D}_{\mathrm{flow}}$, and this can be explained by the role of the particle interactions and their number. The shape factor is linked mainly to cohesiveness, flowability and angle of difference. These relations are quite logical [19].

Table VII provides an overall view of the 4 main powders studied, and new comparisons. It is possible to extract a special size class [100-112 $\mu \mathrm{m}$ ] from this skim milk powder by simple sieving. It presented very good end-use properties in relatively low proportions $(6 \%)$, with a flowability value of 65. Close to monodispersed populations as a consequence of sieving, all the other fractions over $112 \mu \mathrm{m}$ also presented normal flowability performance (without problems for the industry) that were better than the initial powder with the poor flowability value of 43 .

Two attempts to prepare binary mixes to obtain a better percentage of good flowability powders using this special fraction failed both with large [140-160 $\mu \mathrm{m}]$ and with fine [71-80 $\mu \mathrm{m}$ ] particles. However, the two mixes presented different properties. It is now evident that mixing the previously 
Table VII. Comparison of powders and binary mixes (prepared in the same fraction ratio as the initial powder).

\begin{tabular}{|c|c|c|c|c|c|c|c|c|c|c|c|c|c|}
\hline Sample & $\begin{array}{l}\text { D50 } \\
(\mu \mathrm{m})\end{array}$ & $\begin{array}{c}\text { Angle of } \\
\text { repose } \\
\left(^{\circ}\right)\end{array}$ & $\begin{array}{c}\text { Angle of } \\
\text { fall } \\
\left({ }^{\circ}\right)\end{array}$ & $\begin{array}{c}\text { Angle of } \\
\text { difference } \\
\left(^{\circ}\right)\end{array}$ & $\begin{array}{c}\text { Angle of } \\
\text { spatula } \\
\left(^{\circ}\right)\end{array}$ & $\begin{array}{l}\text { Compres- } \\
\text { sibility } \\
(\%)\end{array}$ & $\begin{array}{c}\text { Hausner } \\
\text { ratio }\end{array}$ & $\begin{array}{l}\text { Gel- } \\
\text { dart } \\
\text { class }\end{array}$ & $\begin{array}{l}\text { Density } \\
\text { increase by } \\
\text { tapping } \\
\left(\mathrm{kg} \cdot \mathrm{m}^{-3}\right)\end{array}$ & $\begin{array}{c}\text { Porosity } \\
\text { (\%) }\end{array}$ & $\begin{array}{c}\text { Particle } \\
\text { density } \\
\text { Pycno } \\
\left(\mathrm{kg} \cdot \mathrm{m}^{-3}\right)\end{array}$ & $\begin{array}{c}\text { Loose } \\
\text { bulk } \\
\text { density } \\
\left(\mathrm{kg} \cdot \mathrm{m}^{-3}\right)\end{array}$ & $\begin{array}{c}\text { Tapped bulk } \\
\text { density } \\
\left(\mathrm{kg} \cdot \mathrm{m}^{-3}\right)\end{array}$ \\
\hline $\begin{array}{l}\text { M1 } \\
41 \%[100-112] \\
59 \%[140-160]\end{array}$ & 132 & 40.8 & 28.1 & 12.7 & 65.1 & 14.95 & 1.18 & A & 96 & 58.0 & 1280 & 543.40 & 639 \\
\hline ISMP & 66.3 & 41.8 & 20.5 & 20.5 & 74.5 & 31.3 & 1.46 & $\mathrm{C}$ & 250 & 58.6 & 1300 & & \\
\hline $\begin{array}{l}\text { Best fraction } \\
{[100<D<112]}\end{array}$ & 98.0 & 35.6 & 23.0 & 15.7 & 53.6 & 17.6 & 1.21 & A & 135 & 56.6 & 1273 & & \\
\hline $\begin{array}{l}\text { M2 } \\
38 \%[100-112] \\
62 \%[71-80]\end{array}$ & 92.8 & 43.1 & 26.6 & 16.5 & 62.8 & 23.89 & 1.31 & $\mathrm{AC}$ & 171 & 58.0 & 1293 & 544.80 & 715 \\
\hline
\end{tabular}

separated fractions is not a solution to improve end-use properties. However, some mix properties may be appropriate for behaviour in some specific unit operations such as compression, measuring out from bins, regularity of flow, packaging, etc. On the other hand, simple extraction by sieving of the size fraction [100-112 $\mu \mathrm{m}]$, with fairly good end-use properties, does not affect the properties of the rest (94\%) of the ISMP.

As the ISMP was obtained with a classical drying processing plant, and not by Multi-Stage Dryer processing [17], this result raises some industrial issues: you can avoid granulation and still achieve particularly good flowability properties for a small fraction of the powder. Large drying plants could integrate this new factor in their process and production management, decisions and planning. This central fraction [100-112 $\mu \mathrm{m}]$ presents properties that can lead to new facilities in food processing and formulation.

The concept of sieving a large fraction of the overall production to get a product with new properties is already known and has often been used in the past for minerals, pharmaceuticals and chemicals. It could now also be applied to dairy plants.

Acknowledgements: We thank the "Pays de Loire" region for awarding a post-doctorate scholarship to L. Mekkaoui for this research programme.

\section{REFERENCES}

[1] AFNOR, Tamis et tamisage-Analyses granulométriques-Tamisage de contrôle, norme NF X 11-507, 1970.

[2] Aulton M.E. (Ed.), The science of dosage form design, Pharmaceutics Churchill \& Livingstone, Edinburgh, 1988.

[3] Carr R.G. Jr., Classifying flow properties of solids, Chem. Eng. 72 (1965) 69-73.

[4] Carr R.G. Jr., Evaluating flow properties of solids, Chem. Eng. 72 (1965) 163-168.

[5] Carr R.G. Jr., Particle behaviour, storage and flow, Brit. Chem. Eng. 15 (1970) 15411549.

[6] Devise B., Delacourte-Thibaut A., Guyot J.C., Traisnel M., Mise au point d'une technique d'étude simplifiée de l'écoulement des poudres destinées à la compression, Pharm. Acta. 50 (1975) 432-446.

[7] Geldart D., Wong A.C.Y., Fluidization of powders showing degrees of cohesiveness. I. Bed expansion, Chem. Eng. Sci. 39 (1984) 1481-1488.

[8] Geldart D., Harnby N., Wong A.C.Y., Fluidization of cohesive powders, Powder Technol. 37 (1984) 25-37.

[9] Graindorge P., Contribution à l'étude par analyse des données des modes d'action des additifs d'écoulement pulvérulents en mélange avec des poudres alimentaires, Thèse Univ. Nantes, France, 1992.

[10] Graindorge P., Ilari J.L., Traitement statistique de données issues d'analyse sensorielle de poudres de produits laitiers, in: Proceedings 1er Congrès Agro-Industrie et Méthodes Statistiques, Angers, France, juin 1990, pp. 273-282. 
[11] Graindorge P., Ilari J.L., Contribution à l'étude des modes d'action des additifs d'écoulement en mélange avec du jaune d'oeuf en poudre, in: Proceedings $2^{\mathrm{e}}$ Congrès AgroIndustrie et Méthodes Statistiques, Nantes, France, juin 1991, pp. 337-346.

[12] Hausner H.H., Friction conditions in a mass of metal powder, Int. J. Powder Metal. 3 (1967) 7-13.

[13] IDF, Dried milk and dried cream - Determination of water content, Standard 26A, 1993.

[14] Ilari J.L., Multidimensionnal statistical methods to drive and/or manage a multi stage dryer, in: 1st Int. Symp. on Spray Drying of Milk products, Rennes, France, 16 oct. 2001, p. 26.

[15] Ilari J.L., Flow properties of industrial dairy powders, Lait 82 (2002) 383-399.

[16] Ilari J.L., Réflexion sur des méthodes moins classiques et la préparation des poudres à la mesure, in: Comptes-rendus "Etat de l'art sur la coulabilité des systèmes divisés", SFGP, "Solides divisés", Compiègne, France, 2002 .
[17] Ilari J.L., Loisel C., La maîtrise de la fonctionnalité des poudres, Process 1063 (1991) $39-43$.

[18] Kouadri-Henni A., Benhassaine A., Corrélations granularité coulabilité : étude d'un mélange bimodal d'une farine de blé tendre, in: Récents Prog. Génie Procédés, vol.15 (77), 2001, pp. 109-114.

[19] Loisel C., Contribution à l'étude des propriétés rhéologiques de quelques poudres alimentaires, Thèse Univ. Nantes, France, 1988.

[20] Pilpel N., The flow properties of magnesia, J. Pharm. Pharmacol. 16 (1964) 705-716.

[21] Turra M., Zimmermann I., Interparticulate cohesion forces and flowability of a free flowing excipient in dependency on particle size, in: Partec 98, Nuremberg, Germany, 1998 , p. 239.

[22] Wouters I.M.F., Geldart D., Characterising semi-cohesive powders using angle of repose, Part. Syst. Charact. 13 (1996) 254-259. 